MARTY, Éric. Roland Barthes - O ofício de escrever. Rio de Janeiro: Bertrand do Brasil, 2009.

\title{
UM DEGRADÊ DE RETRATOS
}

\section{Juliana Gonçalves Bratfisch ${ }^{1}$}

É lugar comum entre os escritos da modernidade afirmar que a mediação entre pensamento e expressão está fadada ao fracasso. Roland Barthes esboça uma resposta para esta questão, formando um conjunto de escritos nos quais insiste em escrever repetidamente sobre o mesmo assunto, por entre uma grande variedade de temas e formas abordados: a literatura como uma chama para fazer literatura.

Nesse vasto conjunto de escritos temos, sobretudo, um imenso diário de escritor com reflexões exigindo subjetividade sobre os atos de escrita e leitura. Nessa repetição em que os textos afirmam e afirmam-se infinitamente, fragmentando-se e tornando-se um entrelugar, uma não-obra esboça uma possível resposta à impossibilidade da medição entre pensamento e expressão, refletindo sobre a própria impossibilidade dessa mesma mediação.

Um dos lançamentos editoriais recentes mais instigantes sobre o escritor-crítico é Roland Barthes - $O$ ofício de escrever, de Éric Marty, amigo de Barthes, editor de suas obras completas pelas edições Seuil e atual professor da Universidade Paris VII.

O livro é dividido em três partes coincidentes com três leituras: a primeira parte, intitulada "Memória de uma amizade", narrativa autobiográfica sobre a convivência entre discípulo e seu mestre durante seus últimos anos de vida; a segunda, uma reunião dos prefácios escritos para figurar nos cinco volumes das obras completas; e, por último, um exercício de leitura coletiva sobre um livro de Barthes, a transcrição de um seminário de Marty, que ocorreu na Universidade Paris VII, sobre Fragmentos de um discurso amoroso.

Desembocando numa linguagem mais acadêmica, o livro parte de uma narrativa autobiográfica, aperitivo para quem talvez não conheça Roland Barthes como um personagem da vida literária francesa. Um caminho escolhido para seduzir o leitor em torno de seu objeto e prepará-lo gradativamente para enfrentar a difícil escritura barthesiana.

Assim como Éric Marty, que nos conta isso no prefácio, admiro e me envolvo bastante ao ler testemunhos sobre escritores, seja sob o formato de carta, diário ou narrativa. Há nessas leituras certo sabor residente na fantasia dos bastidores da vida cotidiana e da escrita, gerando uma sensação de pertencimento, de deslocamento físico-

\footnotetext{
${ }^{1}$ Graduanda em Letras pela Universidade de São Paulo, atualmente desenvolve pesquisa de Iniciação Científica intitulada "Roland Barthes e a escritura do fragmento a partir da leitura de Sade", orientada pela Profa. Dra. Verónica Galíndez-Jorge e financiada pela FAPESP. E-mail: juliana.bratfisch@usp.br 
temporal bem distinto das narrativas totalmente ficcionais. A sensação que temos ao ler esse gênero de relato é a participação num recorte da história real por meio da ficção.

O relato autobiográfico começa com o jovem Éric Marty que sobe habitualmente as escadas de um prédio e pára frente a uma porta, ouvindo o som de um piano. Quem o toca do outro lado é Barthes que, ao ouvir a campainha, pára instantaneamente e vem abrir a porta.

Ouço através da porta o som do piano. Escuto. São alguns dos Prelúdios de Debussy, ou uma peça de Schumann, ou Fauré, já não me lembro. Espero um pouco. Assim que tocar a campainha a música se interromperá. Toco a campainha. Como um autômato, Barthes pára de tocar. Isso me fascina. (p.25)

A interrupção da música ao soar a campainha da casa de Barthes é para Marty uma espécie de madeleine proustiana. Símbolo de abertura, de descoberta, a porta está presente na narrativa como uma tênue barreira que rompe a temporalidade. Nós, leitores, temos a sensação de estarmos mais próximos de desvendar a intimidade de alguém que nostalgicamente irá nos deixar em breve (já sabemos o trágico final da narrativa). A própria suspensão sugerida por Marty, ao esperar para tocar a campainha, dá a sensação de que entrar por essa porta é algo muito precioso e esperado.

A partir desse ponto a reconstituição dos gestos, das atitudes cotidianas e de certos pensamentos e percursos de ambos, se desenha, através do olhar fascinado, que relata gradativamente a intimidade desenvolvida entre discípulo e mestre. No texto aparece grande parte do processo de desenvolvimento crítico de Barthes, passando inclusive pela tomada de notas cotidiana, da qual Marty se orgulha de fazer parte: "Ele leva sempre com ele um caderninho de espiral que de vez em quando tira do bolso para anotar alguma coisa, às vezes alguma coisa que eu disse". (p.45)

A relação discípulo/mestre me parece ser um dos pontos cruciais da reflexão suscitada pela narrativa. Qual o papel de um mestre? Em que consiste a relação? Éric Marty esboça perguntas semelhantes que desembocam na reflexão de como se pautavam as atitudes de Barthes em relação aos seus discípulos.

O discípulo nunca tem certeza de que está diante de enunciados verdadeiros, isso importa pouco. É por isso que o discípulo deve ser jovem. Tímido. $\mathrm{O}$ que vale é a força de afirmação do enunciado e os esforços que deve fazer para penetrar na matéria literalmente em todos os sentidos. (p.43)

A segunda parte do livro, intitulada "A Obra", inicialmente pode ser tomada como um bom roteiro crítico para situar o leitor diante dos textos de Barthes. Cinco textos cronologicamente dispostos, esse miolo do livro me parece editorialmente dispensável aos leitores franceses, já que os mesmos textos podem ser encontrados nas edições da Obras Completas. Entretanto, para o leitor brasileiro que não domina o idioma original é um grande ganho a disposição desses textos não só pelo caráter de introdução à obra, mas por tecerem hipóteses sobre os caminhos percorridos por Barthes em seu percurso escritural. 
O seminário sobre Fragmentos de um discurso amoroso, configurando a terceira parte do livro, se insere na tradição dos seminários na qual Barthes e toda sua geração se incluem. Parte mais acadêmica e densa, proporciona uma leitura aprofundada do texto barthesiano. É indispensável reler paralelamente a publicação tema do seminário de Marty para iniciar qualquer diálogo com seus escritos que pressupõem um leitor mais experiente e conhecedor dos textos de Barthes.

Éric Marty diante do impasse da reconstituição escrita de seu caminho crítico, opta por um percurso crítico paralelo ao seu mestre. Ao afirmar Barthes três vezes e de três maneiras distintas, fragmenta a obra barthesiana e cria uma fina nuance de olhares, se distanciando do sujeito (narrativa autobiográfica) ao texto (seminário sobre Fragmentos). 0 autor, então, ao fotografar Barthes através de sua câmera clara, grafa distintos retratos de seu mestre, dispondo sobre sua escrivaninha três nuances da sua meditação sobre a literatura. 
Artigo recebido em: 03/10/09

Artigo aprovado em: 07/10/09

Referência eletrônica: BRATFISCH, Juliana G. "Um degradê de retratos", Revista Criação \& Crítica (online), n. 3, p.97-99, 2009. 